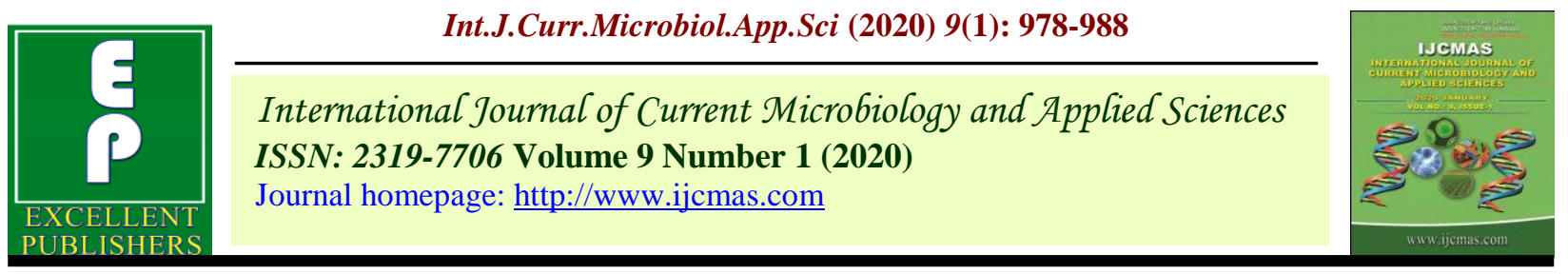

Original Research Article

https://doi.org/10.20546/ijcmas.2020.901.110

\title{
Assessment of Rainfall of Northern Transitional Zone in Karnataka for Agricultural and Meteorological Drought
}

\author{
S. Lokesh ${ }^{1^{*}}$, H. D. Shilpa ${ }^{1}$, S. Navyashree ${ }^{2}$ and Jasti Venkata Satish ${ }^{2}$ \\ ${ }^{1}$ University of Agricultural Sciences, Dharwad, India \\ ${ }^{2}$ Kerala Agricultural University, Thrissur, India \\ *Corresponding author
}

\section{A B S T R A C T}

Keywords

Rainfall,

Agriculture,

Drought, Kharif,

Rabi

Article Info

Accepted:

15 December 2019

Available Online:

20 January 2020
Rainfall assessment plays a major role in designing the mitigation measures and getting the sustainable yield in the dry lands. Weather cock software was used for the analysis and incomplete gamma test was conducted for measuring the probability of rainfall occurrence. Rainfall assessment of the Northern Transitional Zone has observed that, the zone has been often prone to meteorological and agricultural drought. $21^{\text {st }}$ to $24^{\text {th }}$ and 31 to $34^{\text {th }}$ weeks are often prone to drought in Kharif and $41^{\text {st }}$ to $47^{\text {th }}$ weeks are affected in Rabi. Probability of getting normal rainfall of norther transitional zone was only 50 per cent. Government should strengthen the forecasting schemes and should make adoption of soil and water conservation measures to be compulsory.

\section{Introduction}

Rainfall is the respiratory system of agriculture, in India nearly 68 per cent of the area is under rain fed condition. Rainfed area is contributing considerably to the (44\%) to the total food grain production in the country (Vijayan, 2016).In recent years due to climatic aberrations, rainfall is varying both spatially and temporarily (Kumar et al., 2010; Asharaf and Ahrens, 2015), these variations have worsened the agriculture situation along with the variation in temperature and these variations were amplified in $21^{\text {st }}$ century
(Guhathakurta and Rajeevan, 2008). Number of rainy days in a year were decreasing over the years i.e. rainy days with rainfall between $5 \mathrm{~mm}-10 \mathrm{~mm}$ were decreasing along with the increase in the heavy rainfall days $(>10 \mathrm{~mm})$ and these variations are expected to increase in the coming days (Bal et al., 2016). There by it is confirmed that the dry spell in a year is increasing, this effect is much higher in case of South-West Monsoons (Bal et al., 2016) where 80 percent of the rainfall of the country is received and every farmer of the country will be cultivating. Similar observations were made in case of North-East 
Monsoon season i.e. 2-5 percent increase in the extreme rainfall events, similar results were also identified for summer by Rajendran et al., (2013) and from these studies it is cleared that dry spells were increasing in the country over the years. These variations in rainfall have worsened the situation of dryland farmers along with the other climatic complications like increase in temperature (Kumar et al., 2009; Kumar et al., 2013 and Kumar et al., 2013). Hence, suitable action plans viz., weather based cropping system, short duration varieties, water conservation etc. needed to be developed for the betterment of the dry land farmers. Studies have shown that with the change in cropping pattern, water use efficient crop, soil and water conservation measures etc. have helped the dry land crops to overcome from the moisture stress conditions and added to achieve the desired yield and returns (Desai et al., 2007; Chavai et al., 2015). Hence, a detailed rainfall assessment of a particular place/region/ climatic zones are needed for designing the effective mitigation techniques and policy measures for dry spells and drought situations.

The present study has been carried out for Dharwad district which fall under Northern Transitional Zone of Karnataka for designing the effective agricultural planning and drought management. Northern Transitional Zone is a hot, dry and sub-humid region with an annual rainfall of $>850 \mathrm{~mm}$. Out of which 61 percent of the rainfall is received from south west monsoon and in the Kharif (430 $\mathrm{mm}$ ) season, 19 per cent of rainfall from the northeast monsoon (Nandeesha, 2015), 15 per cent of rainfall in the pre-monsoon season and remaining as off season showers. Sorghum, maize, groundnut, onion, redgram and cotton are the important kharif crops and cotton $(17.55 \%)$ has area sown in kharif. In rabi, sorghum, chickpea and wheat were the important crops cultivated and chick pea is leading in rabi season. And the district has higher cropping intensity (155.27 \%) compared to state and country (Tirlapur and Mundinmani, 2015). The present study has been conducted in order to analyze the spatial and temporal variability of rainfall in the Northern Transitional Zone of Karnataka and to identify the Meteorological and Agricultural droughts, assist the farmers and policy, makers.

\section{Materials and Methods}

Daily rainfall data recorded at the Main Agricultural Research Station Dharwad has been collected from 1985 to 2016 i.e. for the total period of 32 years. Meteorological drought and agricultural drought for agricultural planning were analyzed using weather cock.

\section{Results and Discussion}

Weekly rainfall in Fig 1, indicates thatnorth transitional zone receives rainfall throughout the year, weekly rainfall was more than $5 \mathrm{~mm}$ in almost 34 weeks i.e. from $15^{\text {th }}$ week and to $47^{\text {th }}$ week. Rainfall showed increasing trend from $8^{\text {th }}$ week and reaches highest in $31^{\text {st }}$ week and after which reduces till $37^{\text {th }}$ week and increases again for another few weeks. Highest rainfall has been observed in $40^{\text {th }}$ week $(39 \mathrm{~mm})$ during South West Monsoon season and lowest rainfall was observed in last week of December and in the few weeks of January and March.34 weeks in a year are getting the rainfall more than five millimeter of rainfall. From the Fig 1 it is confirmed that rainfall is highest in kharif season $(425 \mathrm{~mm})$ and followed rabi $(184 \mathrm{~mm})$ and summer seasons $(183 \mathrm{~mm})$. In kharif season rainfall was high and it has increasing pattern till $31^{\text {st }}$ week and later it took decreasing trend and the probability of occurrence of drought was also more. Comparatively summer season was having well distributed rainfall throughout the 
season, whereas in rabi season rainfall was concentrated only in the few initial weeks.

Meteorological drought index was constructed based on the deviation of rainfall from its normal, if the deviation was between 0 and 25 per cent then it is considered as "Mild Drought" year (Table 1 and 2). Similarly, if the deviation is between 25 and 50 per cent it will be considered as "Moderate Drought" year and if the deviations is more than 50 per cent it will be considered as Severe Drought. In the 32 years of study, North-Transitional Zone has faced six per cent (2 years) severe drought years followed by 13 per cent of mild drought years (4 years), 25 per cent of mild drought years (8 years) and there was No Drought in 56 per cent of the years (18 years). Among the severe drought affected years, 2003 (Table 2) was the worst drought affected year with -75.53 per cent deviation in rainfall and it was followed by $2001(-65.14 \%)$. In the 13 per cent of the moderate droughts years 2002 was affected more $(-49.48 \%)$ and least year was $2000(-26.70 \%)$. In the mild drought affected years, $1989(-24 \%)$ was the highly deviated year, it was followed by $1985(-23.13 \%)$ and least deviated year was 2015 (0.19\%).

Analysis of agricultural drought weeks has been done using the weather cock software for both kharif and rabi seasons. Dry spells or drought days for 4 or more consecutive weeks i.e. deviation in rainfall by $>75$ per cent for continues 4 weeks were identified by using the weather cock. In the 32 years, 11 years have faced the agricultural drought in kharif season and 2002 have faced two periods of dry spells (Table 3). Normally drought has aroused from $22^{\text {nd }}$ week to $28^{\text {th }}$ week (4 times)or from $34^{\text {th }}$ week to $40^{\text {th }}$ week (5 times), the prior one was early drought and later one will be mid drought. The early drought is due to failure in onset of monsoon it will be generally from last week of May to first week of July where the major activities viz., land preparation and sowing of the crops will take place (Ramakrishna, 2007; Anonymous, 2019a). Early drought will affect the sowing of major crops of kharif season in the Northern Transitional zone which includes sorghum, maize, cotton, groundnut redgrametc (Tirlapurand Mundinamani, 2015; Kadapatti and Bagalkoti, 2014; Anonymous, 2019).Early drought affects the establishment of crops on field and it mainly affects the imbibition process and makes the seed to croak (Leila, 2007) and in later stages it affects the rooting of the crops by reducing the rooting length and thereby it also affects the shoot length or physiological process in the later stages(Shekari, 2000; Zareian, 2004). Biradar and Sridhar (2003) studied the impact of drought on agriculture in 2003 and were identified that sowing was not done in 50 per cent of the area in Karnataka and was due to early drought i.e. drought in 22nd week to 28th weekand similar results were also identified by Lokesh and Poddar (2014) and 53 per cent of the area was affected in Karnataka and similar results were observed for Vijayapura (Bijapur) District in 2012 where 42 per cent of the area was affected (Lokesh and Poddar, 2012). Hence in order to overcome early drought effects farmers should go for maintaining the community nursery and crops should be transplanted into the main field. Alternative crops/less duration varieties can also be used once the rainfall starts and if the drought issevere re-sowing can be taken up or if it is short-lived then gap filling recommended (Ramakrishna, 2008). Experiments conducted by Kiran and Lingaraju (2005), Vinchurkar and Ingole (2012), Radder et al., (1991) showed that the sorghum could get the 34.19 per cent, 63.64 per cent and 68.87 per cent of increased yield comparatively to the yield under drought condition. Hence, it is advisable to the farmers to go for the moisture conservation technologies and water conservation 
techniques which add to get the increased yield at the time of drought situation.

North transitional zone also faced in another phase of drought during kharif seasons i.e. from $34^{\text {th }}$ week to $40^{\text {th }}$ week for 5 times in the 32 years of study period (Table 3 ). This phase of drought is also called as mid-season drought, it mostly coincides with booting stage, flowering stage or physiological maturity of the crops (Ramakrishna 2007, Anonymous, 2019a). Because of the midseason drought, the physiological processes like stem development, photosynthesis, metabolism, stomatal closure and translocation of food materials, processes will be affected (Kabiri, 2010; Rahmani, 2006) also drought may lead to wilting and dying of plants. The mid-season drought decreased the 10 per cent rice yield (Moonmoon and Islam, 2017) and in sorghum, root length, weights were reduced and also it decreased the yield by 50 per cent (Matthews et al., 1990; Mutava et al., 2011).

Bidinger et al., (1991) identified that 58 per cent of the agricultural income was decreased for the households in Andhra Pradesh because of the mid-season drought. In the previous weeks to the $31^{\text {st }}$ week the possibility of getting good rains was high hence the farmers should collect and save the water (farm ponds) from the previous weeks to give the lifesaving irrigation to the crops. Hence drought mitigating measures like weed control and mulching or through long term measures like soil and water conservations should be adopted by the farmers. Government should look into this point of view and should make pass a bill related to soil and water conservation like farmers should be provided with all the subsidies only if farmers are adopting all these soil and water conservation measures on the field. Government should continue to promote the schemes like "KrishiBhagya", where the farmers are provided with the subsidy to adopt the water conservation structures also to divers the cropping and farming systems.

Drought has been identified for the Rabi season using the weather cock software, in the study period of 32 years, the North Transitional zone has faced 6 drought years (Table 4).Important crops grown in rabi season includes wheat, chickpea and safflower these crops are able to survive with lesser rainfall compared to kharif season crops. In rabi season, there was no experience of early droughts and this season has witnessed only mid-season drought hat was identified from $41^{\text {st }}$ week to $47^{\text {th }}$ week. Midseason drought in rabi mostly coincides with vegetative stages of the crops, which affects the physiological processes and affects the biomass production.

A study conducted by Behboudian et al., (2001) identified that drought occurrence in the vegetative stage or flowering stages of chickpea could reduce the biomass and crop yield by 23 per cent and 30 per cent respectively. Zhang et al., (2018) identified that the wheat yield loss would be about 1050 per cent and Sinha et al., (2019)showed that the loss would be $25-75$ per cent based on the severity of the drought. Sinha et al., (2018) evaluated few Indian wheat line for drought resistant and showed that in drought, plant height, number of tiller, leaf area and days taken to maturity were highly affected in drought condition compared to the normal situation and authors also identified that yield characteristics were also differed compared to normal situation. In Karnataka wheat occupied an area of 1.98 lakh ha area with the production of 2.61 lakh tonneswith 25 per cent loss due to drought, the production will reduce to 1.96 lakh tonnes. 
Table.1 Meteorological drought index

\begin{tabular}{|l|c|c|}
\hline \multicolumn{1}{|c|}{ Drought Condition } & No. of years & Drought \\
\hline No Drought & 18 & $56 \%$ \\
\hline Mild Drought & 8 & $25 \%$ \\
\hline Moderate Drought & 4 & $13 \%$ \\
\hline Severe Drought & 2 & $6 \%$ \\
\hline Total & 32 & $100 \%$ \\
\hline
\end{tabular}

Table.2 Meteorological droughts in Northern Transitional Zone 1985 - 2016

\begin{tabular}{|c|c|c|c|}
\hline Year & Annual RF (mm) & Deviation (\%) & Drought Condition \\
\hline 1985 & 551.30 & -23.13 & Mild Drought \\
\hline 1986 & 594.70 & -17.07 & Mild Drought \\
\hline 1987 & 626.00 & -12.71 & Mild Drought \\
\hline 1988 & 749.00 & 04.44 & No Drought \\
\hline 1989 & 545.00 & -24.00 & Mild Drought \\
\hline 1990 & 730.50 & 01.86 & No Drought \\
\hline 1991 & 1104.80 & 54.05 & No Drought \\
\hline 1992 & 824.20 & 14.93 & No Drought \\
\hline 1993 & 806.30 & 12.43 & No Drought \\
\hline 1994 & 741.50 & 03.40 & No Drought \\
\hline 1995 & 731.90 & 02.06 & No Drought \\
\hline 1996 & 686.60 & -04.26 & Mild Drought \\
\hline 1997 & 760.30 & 06.02 & No Drought \\
\hline 1998 & 753.80 & 05.11 & No Drought \\
\hline 1999 & 435.70 & -39.25 & Moderate Drought \\
\hline 2000 & 525.70 & -26.70 & Moderate Drought \\
\hline 2001 & 250.00 & -65.14 & Severe Drought \\
\hline 2002 & 362.30 & -49.48 & Moderate Drought \\
\hline 2003 & 175.50 & -75.53 & Severe Drought \\
\hline 2004 & 586.60 & -18.20 & Mild Drought \\
\hline 2005 & 1011.10 & 40.99 & No Drought \\
\hline 2006 & 866.20 & 20.78 & No Drought \\
\hline 2007 & 1086.20 & 51.46 & No Drought \\
\hline 2008 & 928.90 & 29.53 & No Drought \\
\hline 2009 & 1125.00 & 56.87 & No Drought \\
\hline 2010 & 952.50 & 32.82 & No Drought \\
\hline 2011 & 922.70 & 28.66 & No Drought \\
\hline 2012 & 520.50 & -27.42 & Moderate Drought \\
\hline 2013 & 748.00 & 04.30 & No Drought \\
\hline 2014 & 961.90 & 34.13 & No Drought \\
\hline 2015 & 715.80 & -00.19 & Mild Drought \\
\hline 2016 & 568.20 & -20.77 & Mild Drought \\
\hline
\end{tabular}


Table.3 Agricultural droughts aroused in kharif season

\begin{tabular}{|c|c|}
\hline Year & Drought Week \\
\hline $\mathbf{1 9 8 5}$ & $35-39$ \\
\hline $\mathbf{1 9 8 6}$ & $34-37$ \\
\hline $\mathbf{1 9 9 0}$ & $37-40$ \\
\hline $\mathbf{1 9 9 7}$ & $35-39$ \\
\hline $\mathbf{1 9 9 9}$ & $31-39$ \\
\hline $\mathbf{2 0 0 0}$ & $24-27$ \\
\hline $\mathbf{2 0 0 1}$ & $34-37$ \\
\hline $\mathbf{2 0 0 2}$ & $23-31$ \\
\hline & $34-40$ \\
\hline $\mathbf{2 0 0 3}$ & $22-39$ \\
\hline $\mathbf{2 0 0 4}$ & $23-30$ \\
\hline $\mathbf{2 0 1 5}$ & $28-34$ \\
\hline
\end{tabular}

Table.4 Agricultural droughts aroused in rabi season

\begin{tabular}{|c|c|}
\hline Year & Drought Week \\
\hline $\mathbf{1 9 8 5}$ & $42-47$ \\
\hline $\mathbf{1 9 8 8}$ & $41-47$ \\
\hline $\mathbf{1 9 8 9}$ & $40-45$ \\
\hline $\mathbf{2 0 0 1}$ & $40-47$ \\
\hline $\mathbf{2 0 0 3}$ & $41-47$ \\
\hline $\mathbf{2 0 0 4}$ & $41-47$ \\
\hline
\end{tabular}

\begin{tabular}{|c|c|c|c|c|}
\hline Week & $\mathbf{9 0 . 0 0}$ & $\mathbf{7 5 . 0 0}$ & $\mathbf{5 0 . 0 0}$ & Mean $(\mathbf{m m})$ \\
\hline $\mathbf{1}$ & 0 & 1 & 2 & 1.70 \\
\hline $\mathbf{2}$ & 1 & 1 & 1 & 0.20 \\
\hline $\mathbf{3}$ & 1 & 1 & 1 & 0.10 \\
\hline $\mathbf{4}$ & 1 & 1 & 1 & 0.20 \\
\hline $\mathbf{5}$ & 1 & 1 & 1 & 0.00 \\
\hline $\mathbf{6}$ & 0 & 0 & 2 & 1.90 \\
\hline $\mathbf{7}$ & 0 & 0 & 0 & 0.10 \\
\hline $\mathbf{8}$ & 0 & 0 & 1 & 0.70 \\
\hline $\mathbf{9}$ & 0 & 1 & 1 & 0.60 \\
\hline $\mathbf{1 0}$ & 0 & 1 & 2 & 3.20 \\
\hline $\mathbf{1 1}$ & 0 & 1 & 2 & 1.90 \\
\hline $\mathbf{1 2}$ & 0 & 1 & 3 & 5.80 \\
\hline $\mathbf{1 3}$ & 0 & 1 & 3 & 3.60 \\
\hline $\mathbf{1 4}$ & 0 & 1 & 3 & 3.70 \\
\hline $\mathbf{1 5}$ & 0 & 2 & 5 & 8.40 \\
\hline $\mathbf{1 6}$ & 1 & 2 & 8 & 3.40 \\
\hline $\mathbf{1 7}$ & 1 & 2 & 6 & 8.60 \\
\hline $\mathbf{1 8}$ & 1 & 2 & 9 & 5.40 \\
\hline $\mathbf{1 9}$ & 1 & 3 & 11 & 6.70 \\
\hline $\mathbf{2 0}$ & 0 & 2 & 7 & 3.40 \\
\hline
\end{tabular}




\begin{tabular}{|c|c|c|c|c|}
\hline 21 & 1 & 2 & 8 & 4.50 \\
\hline 22 & 2 & 5 & 15 & 2.30 \\
\hline 23 & 2 & 6 & 17 & 6.80 \\
\hline 24 & 4 & 9 & 19 & 3.10 \\
\hline 25 & 4 & 9 & 20 & 6.60 \\
\hline 26 & 2 & 7 & 18 & 7.40 \\
\hline 27 & 2 & 5 & 14 & 9.90 \\
\hline 28 & 3 & 8 & 20 & 8.50 \\
\hline 29 & 4 & 11 & 25 & 4.30 \\
\hline 30 & 5 & 12 & 27 & 6.10 \\
\hline 31 & 4 & 11 & 27 & 7.00 \\
\hline 32 & 4 & 9 & 21 & 8.20 \\
\hline 33 & 4 & 8 & 16 & 9.10 \\
\hline 34 & 2 & 5 & 12 & 5.20 \\
\hline 35 & 2 & 6 & 15 & 1.00 \\
\hline 36 & 2 & 4 & 11 & 4.50 \\
\hline 37 & 1 & 3 & 8 & 3.00 \\
\hline 38 & 1 & 4 & 15 & 7.10 \\
\hline 39 & 2 & 7 & 22 & 6.60 \\
\hline 40 & 4 & 11 & 28 & 1.40 \\
\hline 41 & 1 & 4 & 13 & 2.00 \\
\hline 42 & 1 & 4 & 14 & 6.70 \\
\hline 43 & 1 & 3 & 10 & 7.60 \\
\hline 44 & 0 & 1 & 4 & 5.90 \\
\hline 45 & 0 & 1 & 4 & 8.00 \\
\hline 46 & 0 & 1 & 5 & 8.40 \\
\hline 47 & 0 & 1 & 4 & 8.40 \\
\hline 48 & 0 & 1 & 2 & 1.90 \\
\hline 49 & 0 & 1 & 2 & 1.20 \\
\hline 50 & 0 & 1 & 2 & 1.90 \\
\hline 51 & 0 & 1 & 2 & 2.70 \\
\hline 52 & 0 & 1 & 1 & 0.50 \\
\hline Total & 62 & 182 & 486 & \\
\hline
\end{tabular}

Fig.1 Pattern of weekly rainfall in Northern Transitional Zone (1985 - 2016)

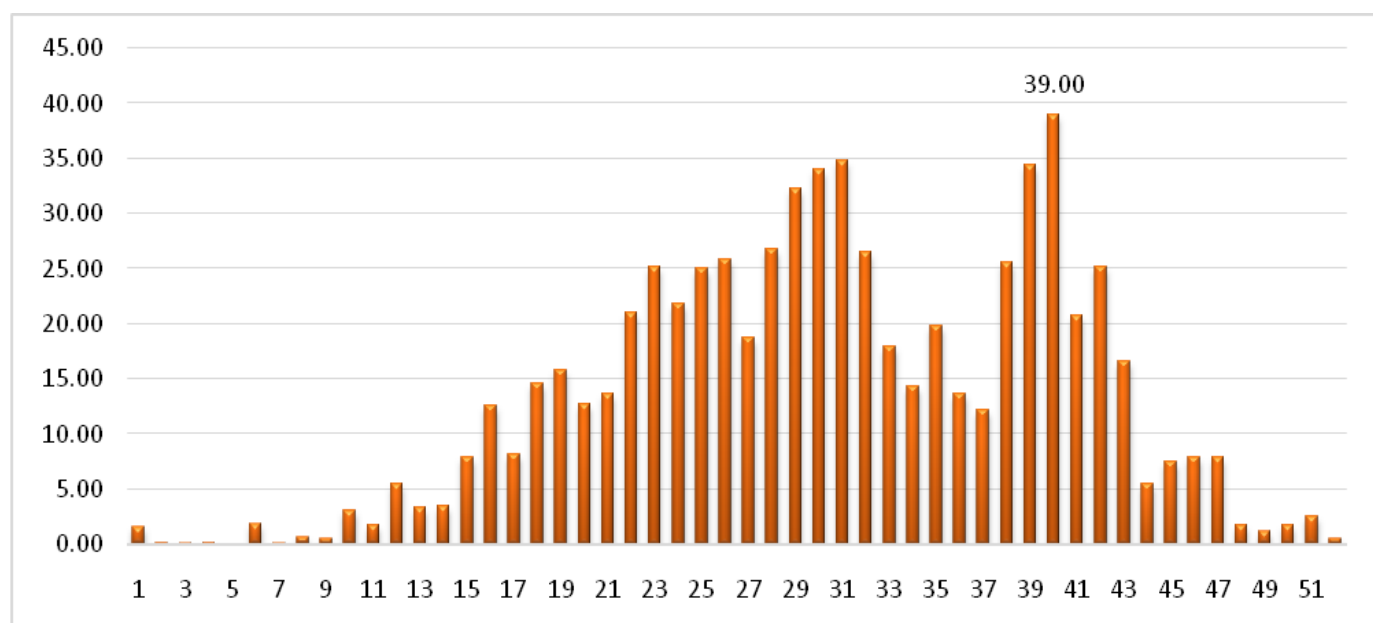


Fig.1 Weekly rainfall distribution level at different probability levels

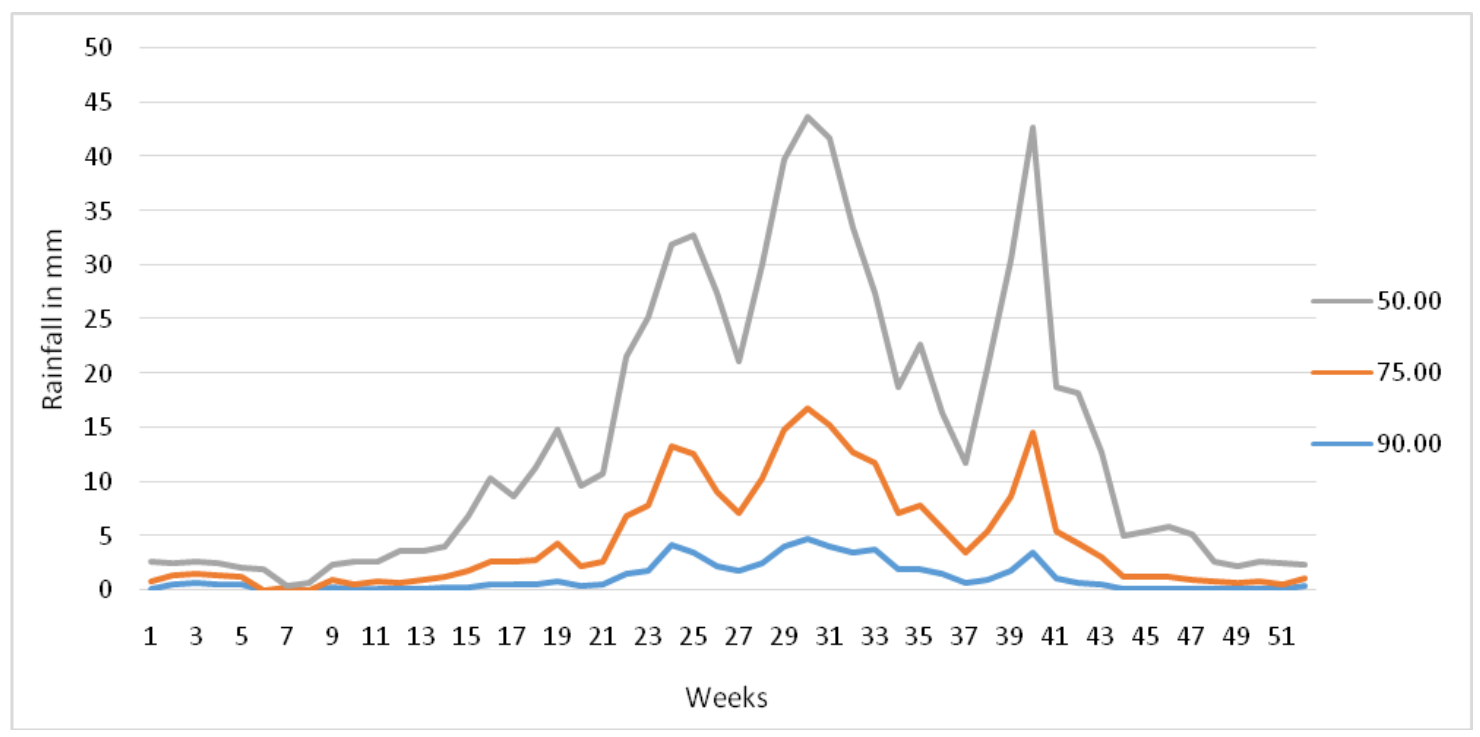

Bengal gram occupied the area of 9.39 lakh ha area with the production of 6.74 lakh tonnes, if the crop exposed to drought there will be a loss of 2.82 lakh tonnes. Hence the drought situations should be mitigated with the different measures like increase the availability of soil moisture with mulching, weed control and loosening of the soil so as to affect the capillary movement of water (Ramakrishna, 2007). In the long run the farmers should be advised to go for adoption of farm ponds to catch the excessive rainfall of the previous weeks (Fig 1) and should be advised to go for short duration verities. Ghosh et al., (2015) and Thippanagoudar (2012) conducted experiments on impact of life saving irrigation on crop yield of wheat at the time of drought seasons, the yield was increased from 48 per cent to 70 per cent in both the experiments respectively. Similar experiments were conducted by Patil et al., (2015), Shirahatti et al., (2016) and Thippanagoudar on chickpea, authors showed that the lifesaving irrigation and drought mitigation measures have increased the yield up to 36 per cent, 60 per cent and 121 per cent respectively. Similarly, Safflower was responded by increased yield of 29 per cent to the drought mitigation measures. Hence it is advisable to the farmers to go for the adoption of both long term and short term corrective and mitigation measures in order to sustain the yields at the drought situations.

Probability of occurrence of rainfall has been calculated by using incomplete gamma test, it was estimated at the probability of levels of 90 per cent, 75 per cent and 50 per cent (Fig 2). From the fig it is confirmed that probability of getting normal or good rainfall $(\geq 486 \mathrm{~mm})$ rainfall in every year is only 50 per cent. The cropping pattern of the region can be modified so as to adjust the minimum rainfall of 50 per cent or farmers should be advised to go for the soil and water conservation measures. The graph also confirms that the rainfall is reducing from $22^{\text {nd }}$ week to $28^{\text {th }}$ week, hence the rainfall in the previous weeks should be carefully collected to use at the time of drought situation. Similarly, the same practice can be followed between $34^{\text {th }}$ to $40^{\text {th }}$ week since the probability of getting good rainfall is only 50 per cent. In the kharif period probability of getting higher rainfall is less hence, rainwater harvesting structure like farm ponds, moisture conservation measures etc., can be planned effectively and implemented. So that 
harvested rainfall water can be used for giving lifesaving irrigation of crops during the critical periods of crops.

In conclusion, rainfall assessment plays a major role in designing the mitigation measures and getting the sustainable yield in the dry lands. Farmers in the North Eastern transitional zone are mostly depending on the rainfall for the production. $22^{\text {nd }}-24^{\text {th }}$ weeks and $34^{\text {th }}$ to $40^{\text {th }}$ weeks are facing the acute shortage of rainfall in the zone, rainfall collection from the previous heavy rainfall weeks helps to save the crops in this period. Similarly, in rabi $41^{\text {st }}$ to $47^{\text {th }}$ week drought prevails, hence these weeks are crucial period of crop cultivation. Probability of getting normal rainfall in every year is only 50 per cent in the zone, government needs to strengthen the forecasting measure in order to send the advanced reminders for the farming community so that they can save the excess rainfall. Adoption of Soil and water conservation measures should be made compulsory to the farmers who want to avail the Government benefits. The important schemes like "KrishiBhagya" should be continued and should ensure that it has reached every farmer.

\section{References}

Asharaf, S. and Ahrens, B. 2015. Indian Summer Monsoon Rainfall Processes in Climate Change Scenarios. J. Climate, 28: 5414 - 5429.

Bal, P. K., Ramachandran, A., Palanivelu, K., Thirumurugan, P., Geetha, R., and Bhaskaran, B. Climate Change Projections over India by a Downscaling Approach Using PRECIS.

Chavai, A. M., Rakshe, U. V., and Shinde, S. B. 2015. Impact of farm pond on the beneficiary farmers in Maharashtra. Int. J. Tropical Agric., 33(4): 3525- 3528.

Desai, R., Patil, B. L., Kunnal, L. B.,
Jayashree, H., and Basavaraja, H. 2007. Impact assessment of farm ponds in Dharwad district of Karnataka. Karnataka J. Agric.Sci., 20(2): 426-427.

GOI [Government of India]. 2016. Statistical Year Book India 2016 (on - line). Ministry of Statistics and Programme Implementation, Government of India. Available:

http://www.mospi.gov.in/statisticalyear-book-india/2016/181.

Guhathakurta, P. and Rajeevan, M. 2008. Trends in the rainfall pattern over India. I. J. Climatol., 28: $1453-1469$.

Kumar K., Singh S. and Singh D. 2009. Winter Season's Climatic variability and impact analysis on wheat productivity in Western Agroclimatic zone of Haryana. J. Agrometeorol. 11 (Spl Issue): 50-53.

Kumar K., Singh S. and Singh D. 2013. Seasonal climatic variability and its impact assessment on wheat productivity using crop modeling techniques in Haryana. J. Agrometeorol. 15 (Spl Issue-I): 25-29.

Kumar P., Singh S. and Singh D. 2013. Regional climate variability analysis and impact assessment on wheat productivity: A case study in Haryana. J. Agrometeorol. 15 (Spl Issue-II): 235237.

Kumar, V., Jain, S. K., and Singh, Y. 2010. Analysis of long-term rainfall trends in India, Hydrol. Sci. J., 55(4): 484 - 496.

Nandeesha. 2015. Agricultural drought assessment using GIS and remote sensing applications in different agro climatic zones of Karnataka state. PhD thesis submitted to University of Mysore. Karnataka. 299p.

Rajendran,K.,Sajani,S.,Jayasankar, C. B., and Kitoh, A. 2013. How dependent is climate change projection of Indian summer monsoon rainfall and extreme events on model resolution? Curr. Sci., 
104(10): 1409 - 1418.

Tirlapur, L. N. AndMundinamani, S.M. 2015. An economic analysis on land use and cropping pattern in Dharwad district. Int. Res. J. Agric. Econ. Statistics, 6(1): 176-181.

Vijayan, R. 2016. Dryland agriculture in India - problems and solutions. Asian J. Environ. Sci., 11(2): $171-177$.

Kadapatti R. G. and Bagalkoti S. T. 2014. Farm Size and Cropping Pattern: A Case Study of Dharwad District in Karnataka State. Int. J. Sci. Res., 3 (10): $2147-2152$.

Anonymous, 2019. Sowing and harvesting period of Principal Crops in Karnataka State (Online). Department of Agriculture, Government of Karnataka. Available:

http://raitamitra.kar.nic.in/stat/22.htm [25th Nov. 2019].

Biradar, N. and Sridhar, K. 2009. Consequences of 2003 Drought in Karnataka with Particular Reference to Livestock and Fodder. J. Human Ecol., 26(2): 123-130.

Lokesh, S. and Poddar, R. S. 2012. Monsoon failure and drought situation in 2012: A case study of Vijayapura district. $J$. Farm Sci., 29(2): 231 - 234.

Ramakrishna, Y. S. 2007. Agricultural Droughts and Their Management. In Ramakrishna, Y. S., Rao, G. G. S. N., Sastry, P.S. N. and Rao, V. U. M.(Eds.). Agricultural Drought: Aspects of micrometeorology. CRIDA, Hyderabad. ISBN NO:978-81-904360-0-7.pp 14 20.

Leila, R. 2007. Response of Tunisian autochthonous pearlmillet to drought stress induced by polyethylene glycol 6000. African J. Biotechnol., 6: 1102 1105

Shekari, F. 2000. Effect of drought stress on phenology, water relations, growth, yield and quality canola, doctorate thesis in the field of Agriculture. M.Sc (Agri) thesis submitted to University of Tabriz, p. 180.

Zareian, J. 2004. Effects of drought on the different stages of growth, and growth traits, varieties of winter canola. MS thesis (Agronomy) submitted to Islamic Azad University of Khorasgan.

Kabiri, R. 2010. Effect of salicylic acid to reduce the oxidative stress caused by drought in the hydroponic cultivation of Nigella sativa (Nigella sativa). MA thesis submitted to Kerman University ShahidBahonar.

Rahmani, n. 2006. Effect of irrigation and nitrogen application on the quantity and quality of medicinal plant Marigold (Calendula Officinalis L.). M.Sc. (Agronomy) thesis submitted to University of Takestan.

Moonmoon, S., and Islam, M. T. 2017. Effect of Drought Stress at Different Growth Stages on Yield and Yield Components of Six Rice (Oryza sativa L.) Genotypes. Fundam. Appl. Agric., 2(3): 285-289.

Matthews, R. B., Reddy, D. M., Rani, A. U., Azam-Ali, S. N., and Peacock,J. M. 1990. Response of four sorghum lines to mid-season drought. I. Growth, water use and yield. Field Crops Res., 25: 279 $-296$.

Mutavaa, R. N., Prasada, P. V. V., Tuinstra, M. R. Kofoid, K. D., Yu, J. 2011.Characterization of sorghum genotypes for traits related to drought tolerance. Field Crops Res., 123: 10 18.

Zhang, J., Zhang,S., Cheng, M., Jiang, H., Zhang, X., Peng, C., Lu, X., Zhang, M., and Jin, J. 2018. Effect of Drought on Agronomic Traits of Rice and Wheat: A Meta-Analysis. Int. J. Environ. Res. Public Health, 15(5): 839.

Sinha, R., Irulappan, V., Mohanraju, B., Suganthi A., and Senthilkumar M. 
2019. Impact of drought stress on simultaneously occurring pathogen infection in field-grown chickpea. Sci. Reports, 9: 5577.

Behboudian, M. H., Ma, Q., Turner, N. C., and Palta, J. A. 2001. Reactions of chickpea to water stress: yield and seed composition. J. Sci. food Agric., 81: 1288-1291.

Tippanagoudar, P. G. 2012. Evaluation of Soil and Moisture Conservation Practices on Productivity of Cropping Systems in Model Watershed Dharwad. $\mathrm{PhD}$ thesis submitted to the University of Agricultural Sciences, Dharwad. 231 p.

Shirahatti M. S., Surkod, V. S., Devaranavadagi, S. B., Chary G. R., Hundekar and Tahshildar, M. M. 2016. Compartment Bunding: A Drought Coping Practice. AICRPDA, RARS, Vijayapura, Karnataka. 6p.

Patil, S. L., Loganandhan, N., and Ramesha, M. N. 2015. Evaluation of chickpea varieties under compartmental bunding in rainfed situation (on-line). Legume Res., LR3496: 1-6. Available: DOI:10.18805/lr.v0iOF.9379.

Ghosh, B. N., Dograa, P., Sharmaa, N.K., Bhattacharyya, R., and Mishra, P.K.
2015. Conservation agriculture impact for soil conservation in maize-wheat cropping system in the Indian subHimalayas. I. Soil Water Cons. Res., 3(2): $112-118$.

Vinchurkar, S. S. and Ingole, N. W. 2012. Sustainable development in watershed area through soil and water conservation activities- A case study (on-line). International Journal of Scientific \& Engineering Research, $3(12)$. Available: https://www.ijser.org/onlineResearchPa perViewer.aspx?Sustainabledevelopment-in-watershed-areathrough-soil-and-water-conservationactivities.pdf [17th Dec 2018]

Radder, G. D., Itnal, C. J., Surkod, V. S., and Biradar, B. M. 1991. Compartment bunding - An effective in-situ moisture conservation practice on medium deep black soil. Indian J. Soil Conservation, 19(1\&2): $1-5$.

Kiran J. A. And Lingaraju, B. S. 2005. Effect of In-situ Moisture Conservation Practices and Nitrogen Levels on Growth and Yield of Rabi Sorghum in Vertisols Under Rainfed Condition. Karnataka J. Agric. Sci., 18(2): 294296.

\section{How to cite this article:}

Lokesh, S., H. D. Shilpa, S. Navyashree and Jasti Venkata Satish. 2020. Assessment of Rainfall of Northern Transitional Zone in Karnataka for Agricultural and Meteorological Drought. Int.J.Curr.Microbiol.App.Sci. 9(01): 978-988. doi: https://doi.org/10.20546/ijcmas.2020.901.110 